\title{
Knowledge Assessment of Residents (PG/NON-PG) Regarding Biomedical Waste Management in a Tertiary Care Hospital
}

\author{
Amit Dumka $^{\# 1}$,Dr Maher Bano ${ }^{\# 2}$, Dr Vinita Rawat ${ }^{\# 3}$ \\ ${ }^{\# 1}$ Dy.Manager (Extension \& Training) / In-charge, Central Bio-Medical Waste Management Treatment Facility, \\ Government Medical College, Haldwani (Nainital) UTTARAKHAND-263139. (dumka.amit@gmail.com). \\ ${ }^{\# 2}$ Assistant Professor, Department of Community Medicine, MLB Medical College, Jhansi (Jhansi) \\ UTTAR PRADESH-284128. (meharbano1204@gmail.com). \\ ${ }^{\# 3}$ Associate Professor, Department of Microbiology, Government Medical College, Haldwani Haldwani (Nainital) \\ UTTARAKHAND-263139. (drvinitarawat@gmail.com).
}

\begin{abstract}
Background: "Bio-Medical Waste" means any waste, which is generated during the diagnosis, treatment or immunisation of human beings or animals or research activities pertaining thereto or in the production or testing of biological or in health camps, including the categories mentioned in rules. Approximately $15-35 \%$ of the Bio-Medical waste is hazardous/infectious and can be injurious to humans or animals and deleterious to environment. It is estimated that India generates around three million tonnes of medical wastes every year and the amount is expected to grow at eight per cent annually.

Objectives: To assess the knowledge regarding new Bio-Medical Waste (Management \& Handling) rules 2016 amongst Resident Doctors (PG-Junior Residents) working in Government Medical College, Haldwani.

Material and Methods: The study comprises of assessment of the knowledge regarding BMW management and disposal as per the Bio-Medical Waste (Management \& Handling) Rules 2016. For this purpose, structured questions were used, and questionnaires were e-mailed to 108 respondents to get the primary data. Out of 108 PGResidents (Junior residents) 55 (50.93\%) responded to the questionnaire e-mailed.

Results: Majority of PG-Residents (65.5\%) did not attend training of BMW management. Only 18.18\% Residents are aware that as per new rules there are 04 categories of waste. Awareness of PG residents about the BMW disposal in different bags was found to be Inadequate and poor. Upto 29\% PG-Residents were found not aware of the prescribed color coding used for the collection of the waste as per the new rules. The process of incineration was known to $61.8 \%$ PG-Residents and the presence of sewerage was known to $56.4 \%$ residents for the disposal of liquid waste. The practices adopted by the PG-Residents in Bio-Medical Waste Management found to be good and their knowledge regarding Hazardous nature of the Bio-Medical Waste is also better i.e. 98.2\%. They are theoretically aware of segregation and waste minimization, but still some are lacking in practice seems to be practically not sound.

Conclusion: The Residents were observed to be either inadequate or poor or lack in knowledge regarding segregation of waste, various color coding as prescribed in the new rules good in theoretical knowledge.

Recommendation: The need of comprehensive training programs on newly formed Bio-Medical waste management and handling is highly recommended to the Residents.
\end{abstract}

Index Terms - Bio-Medical Waste, Tertiary Care Hospital, Knowledge, Resident Doctors.

\section{INTRODUCTION}

Biomedical waste (BMW) is waste generated during diagnosis, treatment or immunization of human beings or animals, or in research activities pertaining thereto, or in the production and testing of biologicals, and is contaminated with human fluids. 1 The waste produced during health care activities carries a higher potential for infection and injury than any other type of waste. ${ }^{1}(1)$

\footnotetext{
${ }^{1}$ Gazette of India. GSR. 343(E) dated 28 March 2016, Biomedical Waste Management Rules, 2016,
}

Recently new Bio-Management Management and Handling rules 2016 has been formulated and executed. It has been observed that Health care waste (HCW) lacks awareness regarding $\mathrm{BiO}$ Medical Waste (BMW) management as per the laid rules. Hence, this study was conducted to access the awareness regarding the newly formed Bio-Medical Waste management rules.

Ministry of Environment and Forests, Government of India, New Delhi, India. 2016, 1-37. 


\section{International Journal of Research in Advent Technology, Vol.7, No.1, January 2019 E-ISSN: 2321-9637 \\ Available online at www.ijrat.org}

\section{MATERIALS AND METHODS}

The study was conducted at Dr. Shusila Tiwari Government Hospital, the associated teaching hospital of Government Medical College, Haldwani. Haldwani is located at $29^{\circ} 13^{\prime} 12^{\prime \prime} \mathrm{N}, 79^{\circ} 31^{\prime} 12^{\prime \prime} \mathrm{E}$. With a population of 156,078 in 2011 , it is also the largest city of the Kumaon region, in the Nainital District, and is one of its eight Subdivisions, being situated in the immediate foothills of Kumaon Himalayas, is also known as the "Gateway of Kumaon". Government Medical College, Haldwani is the only functional medical college with $100 \mathrm{UG}$ (MBBS) and 68 PG (MD/MS) intake capacity in Kumaon region of Uttarakhand as on date. It is a 700 bedded hospital with broad specialties. The Average yearly OPD ranges approx. 350,000 and IPD ranges annual number of approximately 180,000.

The study comprises of assessment of the knowledge regarding Bio-medical waste amongst Residents (PG-Junior Residents) in Government Medical College, Haldwani. Investigational survey of various sources of Bio-Medical Waste generation was done to gain the knowledge of the characteristics and composition of the wastes produced in the various generation sites of the Government Medical College and associated teaching hospital. Thereafter, structured questions were used to obtain primary data from PG Residents working in various departments of the college/hospital using online tool from QuestionProSurvey by sending the questionnaire's url to the Resident's e-mails.

The sample consisted of 118 working Residents in various departments of medical college, Haldwani. The information was obtained from the respondents through a pre-designed self-administered questionnaire. The questionnaire consists of knowledge regarding Biomedical Waste management and handling based on Bio-medical Waste (Management \& Handling) Rules, 2016.

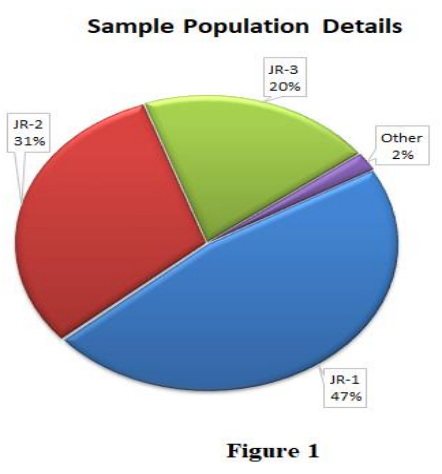

$\square \mathrm{JR}-1$
$=\mathrm{JR}-2$
$\square \mathrm{JR}-3$
$\mathrm{~J}$

\section{OBSERVATIONS:}

The questionnaire was emailed to 118 candidates and out of that only $55(46.61 \%)$ responded back. $47.27 \%(\mathrm{~N}=26)$ are the JR-1 (Junior Resident-1, 1st year PG), $30.91 \%(\mathrm{~N}=17)$ are the JR-2 (Junior resident-2, 2nd year PG), $20 \%(\mathrm{~N}=11)$ are the JR-3 (Junior residents-3, 3rd year PG) and $1.82 \%$ are the Others (Non-PG Junior resident). The details are shown in figure 1 . The study shows that only $34.45 \% \quad(n=19)$ from the total respondents had undergone education/training programme on BioMedical Waste (BMW) during period of service/training, and $65.45 \% \quad(n=36)$ hadn't had undergone any training/education of bio - medical waste management (Figure-2).

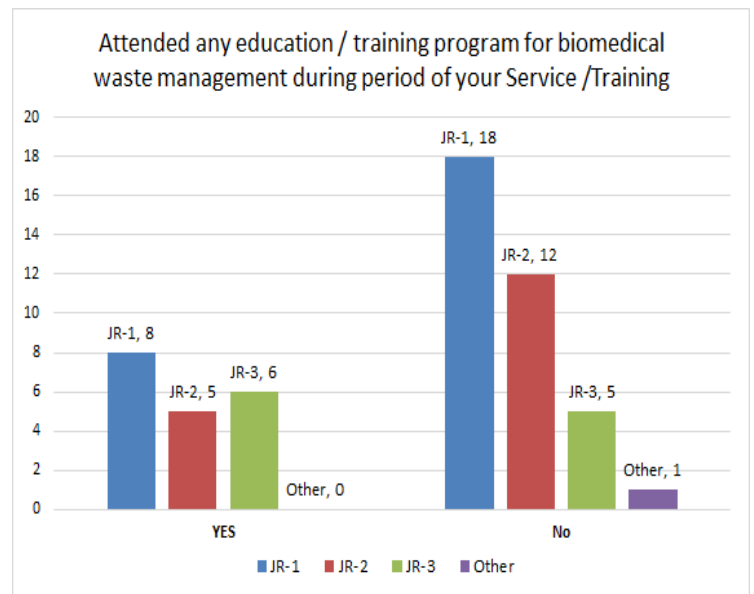

Figure 2

All the respondents are aware that BMW is generated during and treatment of disease. Hospitals and nursing homes are the major source of generation of Biomedical waste is accepted by $98.18 \%(n=54)$ respondents whereas $1.82 \%(n=1)$ thinks there are other sources too.

Figure 3 shows the respondents answer to number of categories of bio-medical waste as per Bio-Medical

Categories of bio-medical waste are there as per Bio-Medical Waste Management Rules

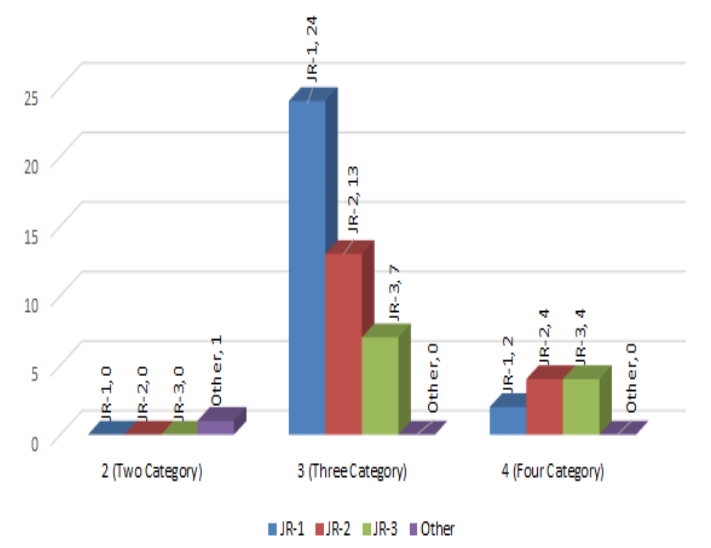

Figure 3 


\section{International Journal of Research in Advent Technology, Vol.7, No.1, January 2019}

\section{E-ISSN: 2321-9637}

\section{Available online at www.ijrat.org}

Waste Management Rules.

According to the data available it was found that $1.82 \%$ thinks there are 02 types of categories available, $18.18 \%$ says there are 04 categories of the waste as per rules and $80 \%$ says there are 03 types of the Bio-medical waste categorization.

96.36\% ( $\mathrm{n}=53)$ participant are aware of the BioMedical Waste rules 2016, whereas two (02) responded replied in negative, either are not aware of bio-medical waste management or pertaining rules (Figure 4).

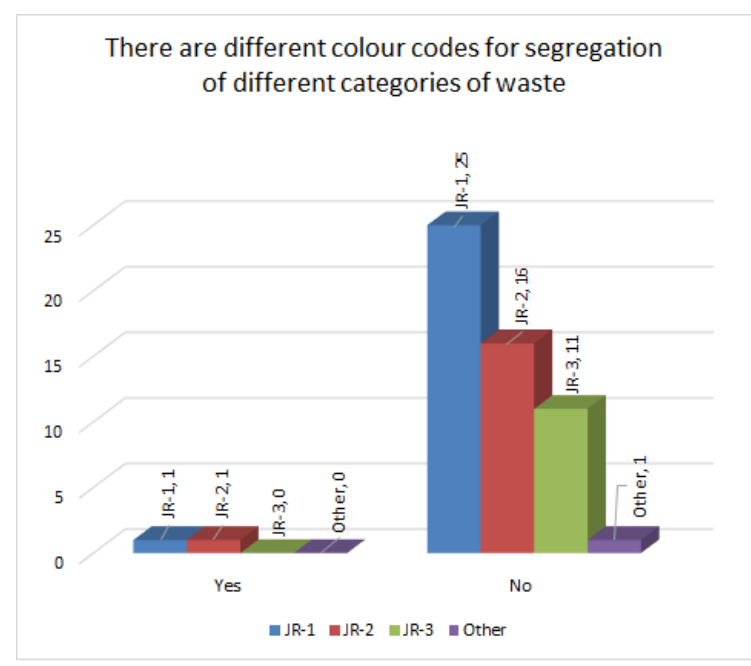

Figure 4

In the study it was observed that $81.82 \%(n=45)$ itemized that solid waste other than Bio-Medical waste is to be collected in black bag/bin, $18.18 \%$ of the respondents stated that blue/Red or yellow bins/bags. From the total population $12.73 \%$ stated yellow bins are used for this purpose, which is very strand with respect to biomedical waste management rules.

In the study it was found that $100 \%$ of the participants are aware of importance of segregation and accept that segregation of waste is the most important step in biomedical waste management. $98 \%$ of the participants agree on the point that biomedical waste management is most effective when done at the source/point of generation. All the participants are aware that Waste minimization is one step which lessens the burden of biomedical waste management. All the participants are aware of hard technologies available for management biomedical waste like needle destroyers, crushers, shredders, sterilization, autoclaves, microwaves and incineration.

It was observed that only $18.2 \%$ are aware that as per new rules there are 04 categories of Bio-Medical Waste and majority of the respondents are not aware of the categorization of bio-medical waste as per 2016 rules. There are $1.8 \%$ of the respondents who says there are 02 categories of the bio-medical waste.

Table 1 Knowledge of PG students about categories, bags, source and rules of BMW

\begin{tabular}{|c|c|c|}
\hline Sr.No. & $\begin{array}{c}\text { Responses of PG } \\
\text { students }\end{array}$ & $\begin{array}{c}\text { Number }(\%) \\
\mathbf{N}=55\end{array}$ \\
\hline & $\begin{array}{l}\text { BMW generated during } \\
\text { diagnosis/treatment }\end{array}$ & $55(100 \%)$ \\
\hline \multirow[t]{3}{*}{2} & $\begin{array}{l}\text { Hospitals are major } \\
\text { source of BMW }\end{array}$ & $\mathrm{N}(\%) \mathrm{n}=55$ \\
\hline & Yes & $54(98.2 \%)$ \\
\hline & No & $1(1.8 \%)$ \\
\hline \multirow[t]{4}{*}{3} & $\begin{array}{l}\text { Number of categories of } \\
\text { BMW }\end{array}$ & $\mathrm{N}(\%) \quad \mathrm{n}=55$ \\
\hline & Four (4) & $10(18.2 \%)$ \\
\hline & Three (3) & $44(80 \%)$ \\
\hline & Two (2) & $1(1.8 \%)$ \\
\hline \multirow[t]{3}{*}{4} & $\begin{array}{l}\text { There are } \\
\text { Yellow/Red/Blue/Black } \\
\text { bags }\end{array}$ & $\mathrm{N}(\%) \mathrm{n}=55$ \\
\hline & Yes & $53(96.4 \%)$ \\
\hline & No & $2(3.6 \%)$ \\
\hline \multirow[t]{3}{*}{5} & $\begin{array}{l}\text { Aware about BMW mgt } \\
\text { rules }\end{array}$ & $\mathrm{N}(\%) \mathrm{n}=55$ \\
\hline & Yes & $50(90.9 \%)$ \\
\hline & No & $5(9.1 \%)$ \\
\hline
\end{tabular}

Very few PG Residents were aware that as per the new guidelines on Bio-Medical waste management there are 04 (four) categories of Bio-Medical waste as per Bio-Medical waste (Management \& handling) Rules 2016 (BMW(M\&H) Rules 2016).

Table 2 Awareness of PG residents about the BMW disposal in different bags

\begin{tabular}{|l|l|c|}
\hline Sr.no & Question asked & Number (\%) \\
\hline 1 & $\begin{array}{l}\text { Solid wastes other than } \\
\text { BMW is collected in } \\
\text { which bag }\end{array}$ & $\mathrm{N}(\%) \mathrm{n}=55$ \\
\hline \multirow{2}{*}{} & Black & $45(81.9 \%)$ \\
\cline { 2 - 3 } & Blue & $2(3.6 \%)$ \\
\hline
\end{tabular}




\section{International Journal of Research in Advent Technology, Vol.7, No.1, January 2019}

\section{E-ISSN: 2321-9637}

\section{Available online at www.ijrat.org}

\begin{tabular}{|c|c|c|}
\hline & Red & $1(1.8 \%)$ \\
\hline & Yellow & $7(12.7 \%)$ \\
\hline \multirow[t]{3}{*}{2} & $\begin{array}{l}\text { Animal wastes collected } \\
\text { in which bag }\end{array}$ & $\mathrm{N}(\%) \mathrm{n}=55$ \\
\hline & Yellow & $\begin{array}{l}54 \\
(98.2 \%)\end{array}$ \\
\hline & Red & $1(1.8 \%)$ \\
\hline \multirow[t]{4}{*}{3} & $\begin{array}{l}\text { Solid wastes } \\
\text { contaminated with } \\
\text { bld/body fluids collected } \\
\text { in which bag }\end{array}$ & $\mathrm{N}(\%) \mathrm{n}=55$ \\
\hline & Yellow & $16(29.1 \%)$ \\
\hline & Red & $38(69.1 \%)$ \\
\hline & Black & $1(1.8 \%)$ \\
\hline \multirow[t]{4}{*}{4} & $\begin{array}{l}\text { Expired medicines } \\
\text { collected in which bag }\end{array}$ & $\mathrm{N}(\%) \mathrm{n}=55$ \\
\hline & Black & $42(76.4 \%)$ \\
\hline & Red & $2(3.6 \%)$ \\
\hline & Yellow & $11(20 \%)$ \\
\hline \multirow[t]{3}{*}{5} & $\begin{array}{l}\text { Chemical wastes } \\
\text { collected in Yellow bag }\end{array}$ & $\mathrm{N}(\%) \mathrm{n}=55$ \\
\hline & Yes & $41(74.5 \%)$ \\
\hline & No & $14(25.5 \%)$ \\
\hline \multirow[t]{3}{*}{6} & $\begin{array}{l}\text { Discarded linen in non } \\
\text { chlorinated yellow bag }\end{array}$ & $\mathrm{N}(\%) \mathrm{n}=55$ \\
\hline & Yes & $39(71 \%)$ \\
\hline & No & $16(29 \%)$ \\
\hline \multirow[t]{3}{*}{7} & $\begin{array}{l}\text { Recyclable wastes in } \\
\text { Red bag }\end{array}$ & $\mathrm{N}(\%) \mathrm{n}=55$ \\
\hline & Yes & $50(90.9 \%)$ \\
\hline & No & $5(9.1 \%)$ \\
\hline \multirow[t]{3}{*}{8} & $\begin{array}{l}\text { Sharp wastes in puncture } \\
\text { proof bags }\end{array}$ & $\mathrm{N}(\%) \mathrm{n}=55$ \\
\hline & Yes & $52(94.5 \%)$ \\
\hline & No & $3(5.5 \%)$ \\
\hline \multirow[t]{3}{*}{9} & $\begin{array}{l}\text { Microbiological wastes } \\
\text { should be pretreated }\end{array}$ & $\mathrm{N}(\%) \mathrm{n}=55$ \\
\hline & Yes & $54(98.2 \%)$ \\
\hline & No & $1(1.8 \%)$ \\
\hline \multirow[t]{3}{*}{10} & $\begin{array}{l}\text { Liquid wastes does not } \\
\text { require any bag }\end{array}$ & $\mathrm{N}(\%) \mathrm{n}=55$ \\
\hline & Yes & $29(52.7 \%)$ \\
\hline & No & $26(47.3 \%)$ \\
\hline
\end{tabular}

During the study it was also found that PG Residents had inadequate knowledge regarding the BioMedical waste disposal in different coloured bags. PG Residents had inadequate knowledge about the collection of solid waste other than Bio-Medical waste $18.1 \%$ of the Residents respondent Blue or Red or Yellow bags for the solid waste other BioMedical waste. $01.8 \%$ of Residents collects Animal waste in the Red bags which are used to collect recyclable item, instead of yellow bags. $70.9 \%$ of the residents mixed. Solid waste contaminated with blood/body fluids in red/black bags instead of yellow begs. Similarly $80 \%$ of the residents collect expired medicine in either red or black bags/bins, instead of yellow bags.

In the study it was found that PG residents had lack of knowledge regarding the collection of the BioMedical waste as per the BMW(M\&H) Rules 2016. $25.5 \%$ of the respondents do not collect chemical waste in yellow bags. $29 \%$ of the PG residents do not collect discarded linen in non-chlorinated yellow bags, still $9.1 \%$ of the residents do not collect recyclable waste in red bags, and $47.3 \%$ of the residents are of the opinion that liquid wastes require bags for collection.

It was found that PG residents had lack of knowledge regarding the disposal of glass ware wastes too, as $10.9 \%$ of the respondents stated that it should be kept is red or black or any one box instead of cardboard with blue coloured marking as per the rules. Similarly regarding disposal of metallic body implants $3.6 \%$ of the respondent stated that it should be kept in store room instead of cardboard box as per the rules.

Table 3 Percept of PG residents about the steps of BMW management

\begin{tabular}{|c|c|c|}
\hline $\begin{array}{l}\text { Sr.n } \\
\text { o, }\end{array}$ & Questions asked & $\begin{array}{l}\text { Number } \\
(\%)\end{array}$ \\
\hline \multirow[t]{3}{*}{1} & $\begin{array}{lr}\text { Steps of BMW are } \\
\text { segregation/collection/storage } \\
\text { /transport/treatment } \\
\text { disposal }\end{array}$ & $\mathrm{N}(\%) \mathrm{n}=55$ \\
\hline & Yes & $54(98.2 \%)$ \\
\hline & No & $1(1.8 \%)$ \\
\hline \multirow[t]{2}{*}{2} & $\begin{array}{l}\text { Segregation is important step } \\
\text { in BMW management }\end{array}$ & $\mathrm{N}(\%) \mathrm{n}=55$ \\
\hline & Yes & $55(100 \%)$ \\
\hline \multirow[t]{3}{*}{3} & $\begin{array}{l}\text { Segregation is effective if } \\
\text { done at source }\end{array}$ & $\mathrm{N}(\%) \mathrm{n}=55$ \\
\hline & Yes & $54(98.2 \%)$ \\
\hline & No & $1(1.8 \%)$ \\
\hline
\end{tabular}




\section{E-ISSN: 2321-9637}

\section{Available online at www.ijrat.org}

\begin{tabular}{|l|l|l|}
4 & $\begin{array}{l}\text { Waste minimisation lessens } \\
\text { the burden of BMW }\end{array}$ & $\mathrm{N}(\%) \mathrm{n}=55$ \\
\cline { 2 - 3 } & Yes & $54(98.2 \%)$ \\
\cline { 2 - 3 } & No & $1(1.8 \%)$ \\
\hline
\end{tabular}

The knowledge of PG residents regarding the steps of BMW management consisting of minimisation, segregation is better i.e $98.2 \%$

Table 4 Knowledge of PG students about the infrastructure/technologies used for BMW management

\begin{tabular}{|c|c|c|}
\hline Sr.No & Questions asked & $\begin{array}{c}\text { Number } \\
(\%)\end{array}$ \\
\hline \multirow[t]{3}{*}{1} & $\begin{array}{l}\text { Needle } \\
\text { cutter/shredder/autoclave/mi } \\
\text { crowave/incineration etc are } \\
\text { the technologies for BMW } \\
\text { management }\end{array}$ & $\begin{array}{l}N(\%) \\
n=55\end{array}$ \\
\hline & Yes & $54(98.2 \%)$ \\
\hline & No & $1(1.8 \%)$ \\
\hline \multirow[t]{3}{*}{2} & $\begin{array}{l}\text { Does needle cutter destroy } \\
\text { needle before disinfection }\end{array}$ & $\begin{array}{l}N(\%) \\
n=55\end{array}$ \\
\hline & Yes & $52(94.5 \%)$ \\
\hline & No & $3(5.5 \%)$ \\
\hline \multirow[t]{3}{*}{3} & $\begin{array}{l}\text { Does microwave treated } \\
\text { BMW wastes acceptable for } \\
\text { disposal in municipal solid } \\
\text { wastes }\end{array}$ & $\begin{array}{l}N(\%) \\
n=55\end{array}$ \\
\hline & Yes & $43(78.2 \%)$ \\
\hline & No & $12(21.8 \%)$ \\
\hline \multirow[t]{3}{*}{4} & $\begin{array}{l}\text { Incinerator converts } \\
\text { combustible wastes into gas } \\
\text { and non-combustible wastes } \\
\text { into ash }\end{array}$ & $\begin{array}{l}N(\%) \\
n=55\end{array}$ \\
\hline & Yes & $34(61.8 \%)$ \\
\hline & No & $21(38.2 \%)$ \\
\hline \multirow[t]{3}{*}{5} & $\begin{array}{l}\text { Sewarage is must for disposal } \\
\text { of liquid wastes and greasy } \\
\text { waste from kitchen }\end{array}$ & $\begin{array}{l}N(\%) \\
n=55\end{array}$ \\
\hline & Yes & $31(56.4 \%)$ \\
\hline & No & $24(43.6 \%)$ \\
\hline
\end{tabular}

The knowledge of PG residents about the technologies like needle cutter/autoclave/ microwave/incinerator is better i.e $98.2 \%$. but the process of incineration was known to $61.8 \%$ residents. Also, the presence of sewage was known to $56.4 \%$ residents for the disposal of liquid wastes.
Table 5 Awareness of PG residents about the hazards of BMW

\begin{tabular}{|c|c|c|}
\hline Sr.No. & Questions asked & $\begin{array}{c}\text { Number } \\
(\%)\end{array}$ \\
\hline \multirow[t]{2}{*}{1} & $\begin{array}{l}\text { Public health affected by } \\
\text { BMW }\end{array}$ & $\mathrm{N}(\%) \mathrm{n}=55$ \\
\hline & Yes & $55(100 \%)$ \\
\hline \multirow[t]{3}{*}{2} & $\begin{array}{l}\text { Improper practices like } \\
\text { dumping of BMW in open } \\
\text { spaces/water } \\
\text { bodies/municipal wastes } \\
\text { spread diseases }\end{array}$ & $\mathrm{N}(\%) \mathrm{n}=55$ \\
\hline & Yes & $54(98.2 \%)$ \\
\hline & No & $1(1.8 \%)$ \\
\hline \multirow[t]{3}{*}{3} & $\begin{array}{l}\text { Does BMW is hazardous } \\
\text { to animals and plants }\end{array}$ & $\mathrm{N}(\%) \mathrm{n}=55$ \\
\hline & Yes & $54(98.2 \%)$ \\
\hline & No & $1(1.8 \%)$ \\
\hline \multirow[t]{2}{*}{4} & $\begin{array}{l}\text { Does all health care } \\
\text { staff/visitors/Patient } \\
\text { attendants are at risk to } \\
\text { hazards of BMW }\end{array}$ & $\mathrm{N}(\%) \mathrm{n}=55$ \\
\hline & Yes & $55(100 \%)$ \\
\hline \multirow[t]{3}{*}{5} & $\begin{array}{l}\text { Sweepers and rag pickers } \\
\text { are at maximum risk to } \\
\text { hazards of BMW }\end{array}$ & $\mathrm{N}(\%) \mathrm{n}=55$ \\
\hline & Yes & $54(98.2 \%)$ \\
\hline & No & $1(1.8 \%)$ \\
\hline
\end{tabular}

Table 6 Practices performed by the PG residents in BMW management

\begin{tabular}{|c|c|c|c|}
\hline Sr.No & Questions asked & 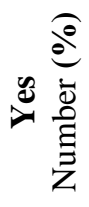 & 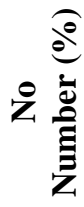 \\
\hline 1 & $\begin{array}{l}\text { Do you segregate } \\
\text { BMW at the point of } \\
\text { generation }\end{array}$ & 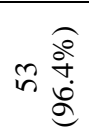 & ㄴํㅇ \\
\hline 2 & $\begin{array}{l}\text { Do you monitor BMW } \\
\text { management as per } \\
\text { norms }\end{array}$ & $n$ & 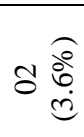 \\
\hline 3 & $\begin{array}{l}\text { Do you promote use of } \\
\text { personal protective } \\
\text { equipment (PPE) in } \\
\text { sanitary attendants }\end{array}$ & $n \stackrel{\overbrace 0}{8}$ & ' \\
\hline 4 & $\begin{array}{l}\text { Do you report any } \\
\text { violations/accidents/dif } \\
\text { ficulties encountered }\end{array}$ & 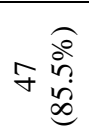 & $\infty \stackrel{\widehat{\rho}}{\stackrel{\stackrel{\rho}{n}}{ \pm}}$ \\
\hline
\end{tabular}


Available online at www.ijrat.org

\begin{tabular}{|c|c|c|c|}
\hline 5 & $\begin{array}{l}\text { Do you use gloves } \\
\text { while handling } \\
\text { infectious wastes }\end{array}$ & 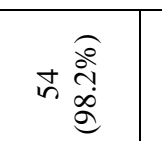 & $\sigma \stackrel{\widehat{o}}{\stackrel{0}{=}}$ \\
\hline 6 & $\begin{array}{l}\text { Do you wash hands } \\
\text { after handling wastes }\end{array}$ & 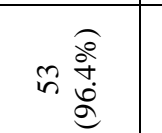 & 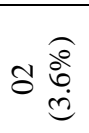 \\
\hline 7 & $\begin{array}{l}\text { Do you throw wastes in } \\
\text { appropriate colour } \\
\text { coded bags }\end{array}$ & $\approx \stackrel{0}{\stackrel{0}{0}}$ & $8 \underset{0}{\stackrel{0}{n}}$ \\
\hline 8 & $\begin{array}{l}\text { Do you put biohazard } \\
\text { symbol on infectious } \\
\text { sample }\end{array}$ & 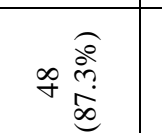 & $s \stackrel{\widehat{o}}{\stackrel{0}{d}}$ \\
\hline 9 & $\begin{array}{l}\text { Do you destroy needles } \\
\text { before disposing } \\
\text { syringes }\end{array}$ & 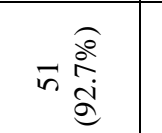 & 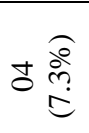 \\
\hline 10 & $\begin{array}{l}\text { Do you mix infectious } \\
\text { and non-infectious } \\
\text { wastes }\end{array}$ & $m \stackrel{\substack{n \\
n}}{n}$ & 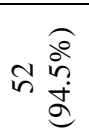 \\
\hline 11 & $\begin{array}{l}\text { Do you } \\
\text { recap/bend/break the } \\
\text { needle }\end{array}$ & $=\frac{\widehat{d}}{\stackrel{0}{d}}$ & F \\
\hline 12 & $\begin{array}{l}\text { Are mouth of waste } \\
\text { bags tied before } \\
\text { transportation }\end{array}$ & 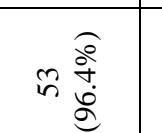 & 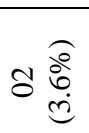 \\
\hline 13 & $\begin{array}{l}\text { What is the volume of } \\
\text { waste in container } \\
\text { when it is filled to } \\
\text { maximum capacity? }\end{array}$ & \multicolumn{2}{|l|}{$\mathrm{N}(\%) \mathrm{n}=55$} \\
\hline & Three-fourth $\left(3 / 4^{\text {th }}\right)$ & \multicolumn{2}{|l|}{$28(50.9 \%)$} \\
\hline & One-fourth $\left(1 / 4^{\text {th }}\right)$ & \multicolumn{2}{|l|}{$19(34.5 \%)$} \\
\hline & Half (1/2th) & \multicolumn{2}{|l|}{$03(5.5 \%)$} \\
\hline & Full & \multicolumn{2}{|l|}{$05(9.1 \%)$} \\
\hline 14 & $\begin{array}{l}\text { How often you change } \\
\text { waste bag in a day? }\end{array}$ & \multicolumn{2}{|l|}{$\mathrm{N}(\%) \mathrm{n}=55$} \\
\hline & $>3$ times & \multicolumn{2}{|l|}{$03(5.5 \%)$} \\
\hline & Thrice & \multicolumn{2}{|l|}{$33(60 \%)$} \\
\hline & Twice & \multicolumn{2}{|l|}{$07(12.7 \%)$} \\
\hline & Once & \multicolumn{2}{|l|}{$12(21.8 \%)$} \\
\hline 15 & $\begin{array}{l}\text { How do you dispose } \\
\text { sharp wastes like } \\
\text { needles/blades etc? }\end{array}$ & \multicolumn{2}{|l|}{$\mathrm{N}(\%) \mathrm{n}=55$} \\
\hline & $\begin{array}{l}\text { Discard in } \\
\text { puncture proof } \\
\text { container before } \\
\text { disinfection } \\
\end{array}$ & \multicolumn{2}{|l|}{$26(47.3 \%)$} \\
\hline & $\begin{array}{l}\text { Disposed for } \\
\text { disinfection }\end{array}$ & \multicolumn{2}{|l|}{$01(1.8 \%)$} \\
\hline & Red bin & \multicolumn{2}{|l|}{$02(3.6 \%)$} \\
\hline & Blue box & \multicolumn{2}{|l|}{$26(47.3 \%)$} \\
\hline 16 & $\begin{array}{l}\text { How do you dispose } \\
\text { plastic infectious }\end{array}$ & \multicolumn{2}{|c|}{$\mathrm{N}(\%) \mathrm{n}=55$} \\
\hline
\end{tabular}

\begin{tabular}{|l|l|l|}
\hline \multirow{4}{*}{} & $\begin{array}{l}\text { wastes } \\
\text { Punctured with } \\
\text { scissor before } \\
\text { disinfection }\end{array}$ & $03(5.4 \%)$ \\
\cline { 2 - 3 } & Yellow bin & $05(9.1 \%)$ \\
\cline { 2 - 3 } & Red bin & $33(60 \%)$ \\
\cline { 2 - 3 } & Blue bin & $05(9.1 \%)$ \\
\cline { 2 - 3 } & Black bin & $09(16.4 \%)$ \\
\hline
\end{tabular}

Only $50.9 \%$ of the PG residents fills the container, up-to $3 / 4$ th which is as per the rules and the rest $49.1 \%$ of the PG residents improperly fill the container. Nearly $60 \%$ change the waste bag thrice in a day. Also, the correct disposal of plastic infectious wastes in red bin was being done by $60 \%$ resident's whereas $40 \%$ of the respondents are not following the rules. Less than half of the residents $(47.3 \%)$ were correctly disposing the sharp wastes like Needles/Blades etc in puncture proof container before disinfection whereas $52.7 \%$ of the respondents found not following the rules.

\section{DISCUSSION / RESULT}

World Health Organization in their fact sheets states that $85 \%$ of hospital wastes are non-hazardous, whereas $10 \%$ are infectious and 5\% are noninfectious but they are included in hazardous wastes (2) 2. Approximately $15 \%$ to $35 \%$ of waste generated from health care facilities is delimited as infectious waste. This range is reliant on the total quantum of waste generated (3)3.

This non-hazardous Bio-Medical Waste is as harmless as any other municipal waste. The remaining hazardous Bio-medical Waste can be injurious to humans or animals and harmful to environment. It is important to realize that if both these types are mixed together then the whole waste becomes hazardous. Similarly, if Bio-medical waste is mixed or gets mixed with general waste, the whole lot of waste is converted to hazardous biomedical waste. It is estimated that annually about 0.33 million tons of hospital waste is generated in

${ }^{2}$ http://www.who.int/mediacentre/factsheets/fs25 3/en/

${ }^{3}$ Glenn, Mc.R\&Garwal, R. Clinical waste in

Developing Countries. An analysis with a Case Study of India, and a Critique of the BasleTWG Guidelines (1999) 


\section{International Journal of Research in Advent Technology, Vol.7, No.1, January 2019 E-ISSN: 2321-9637 \\ Available online at www.ijrat.org}

India and, the waste generation rate ranges from 0.5 to $2.0 \mathrm{~kg}$ per bed per day (4). 4

Any bio-medical waste generated from any "health care facility" (means a place where diagnosis, treatment or immunisation of human beings or animals is provided irrespective of type and size of health treatment system, and research activity pertaining thereto) shall take all necessary steps to ensure that bio-medical waste is handled without any adverse effect to human health and the environment and in accordance the rules. They should make provisions within the premises for a safe, ventilated and secured location for storage of segregated biomedical waste in colored bags or containers in the manner as specified in Schedule I of the rules (1). Schedule-II specifies the standards for treatment and disposal of bio-medical waste and all the waste should be treated and disposed as per these guidelines. Bio-medical waste if not disposed so, may be fatal to the humans, animals and environment finally.

In many studies it has been pointed out that in health care facilities where there is no proper training of the clinicians in bio-medical waste management it was found that the waste minimization and segregation are poor resulting in huge quantity of bio-medical waste generation. Poor segregation and huge amount of bio-medical waste indicates the lack of awareness and practices regarding the disposal of generated bio-medical waste as per the laid rules.

In our study it was found that there was lack of training in $65.5 \%$ PG students with very few $(18.2 \%)$ were aware about the new 4 categories of Bio-Medical Waste as per new rules i.e. BioMedical Waste Management and Handling Rules 2016. Due to Lack of training/education in BioMedical Waste management field 09\% do not take care while Collection/segregation of waste so as to avoid mixing of infectious \& non-infectious waste, resulting in non-compliance to the rules at institute level. Correct knowledge was seen pertaining to the colour coded bags for disposal of general solid waste in $45 \%$ residents, disposal of expired medicines in \% residents. Inadequate knowledge was present about the colour coded disposal of

\footnotetext{
${ }^{4}$ Shekdar, A., \& Patil, A. (2001). Health-care waste management in India. J Environ Manage. 2001 Oct;63(2):211-20. doi: 10.1006/jema.2001.0453., 211-20.
}

discarded chemical wastes and contaminated solid wastes with blood/body fluids in $25.5 \%$ \& $70.9 \%$ respectively. Regarding their percept for infrastructure availability for Bio-Medical Waste management, the presence of sewerage was known to $56.4 \%$ residents and process of incineration was known to $61.8 \%$ residents. About their practices, only $50 \%$ PG residents were filling the waste bag upto three-fourth (3/4th). The cliché lies in segregation of the waste especially infectious waste from the non infectious waste.

The respondents are aware that the health care facilities are the major source of the biomedical waste they too are aware that there are different categories of the bio-medical waste but lacks the true colour coding as per the schedule of the biomedical waste management and handling rules 2016. The respondents don't have proper knowledge of the new categorization and Type of Bags or Containers to be used for disposal as per the new rules. The respondents are aware of the available treatment techniques or options available for the final disposal of the bio-medical but proper knowledge regarding the same was found to be below average. It was found that their percept regarding the segregation and waste minimization of waste was good but segregation techniques are very poor as many respondents use wrong color coding for collection of the bio-medical waste resulting in mixing of waste and taking towards maximization of the bio-medical waste.

The study recommends for the regular training and sensitization through CMEs/seminars of PG residents about the safe, timely and appropriate disposal of Bio-Medical Waste as Bio-Medical Waste management is a team work.

\section{ACKNOWLEDGEMENTS}

The Authors express their appreciation for the Residents who spare their time to participate in the study, Shri Tara Dutt Dholgain for his typing assistance and Shri Shobhit Sharma for image related tasks. The authors also express gratitude to QuestionPro-Survey for development of questionnaire and collection of data.

\section{REFERENCES}

[1] Gazette of India. GSR. 343(E). Gazette of India. GSR. 343(E) dated 28 March 2016, Biomedical Waste Management Rules, 2016, Ministry of Environment and Forests, Government of India, New Delhi, India. 2016, 1-37. 
International Journal of Research in Advent Technology, Vol.7, No.1, January 2019 E-ISSN: 2321-9637

Available online at www.ijrat.org

[2] WHO. Fact Sheet Health Care Waste. [Online] http://www.who.int/mediacentre/factsheets/fs25 $3 / \mathrm{en} /$.

[3] Clinical waste in Developing Countries. An analysis with a Case Study of India, and a Critique of the Basle TWG Guidelines (1999). Glenn, Mc.R \& Garwal, R. 1999.

[4] Shekdar, AV; and Patil, A D; (2001), Healthcare waste management in India. $J$ Environ
Manage. $2001 \quad$ Oct;63(2):211-20. doi: 10.1006/jema.2001.0453., pp. 211-20. 